\title{
Pertumbuhan Planlet Kantong Semar (Nepenthes rafflesiana Jack.) pada Beberapa Media Tanam Selama Tahap Aklimatisasi
}

\author{
The growing of Kantong Semar (Nepenthes rafflesiana Jack.) planlet in several media during \\ acclimatization stage
}

Dendih Sukmadijaya ${ }^{1}$, Diny Dinarti ${ }^{2 *}$, dan Yupi Isnaini ${ }^{3}$

Diterima 27 Agustus 2013/Disetujui 25 Oktober 2013

\begin{abstract}
The purpose of this research was to determine the effect of acclimatization media on $N$. rafflesiana Jack. growth and to obtain the best acclimatization media. This research was conducted at Bogor Botanical Garden from June until September 2009. The research was done in completely randomized design with three replications. Five kinds media were used as treatment, i.e. rice husk charcoal, cocopeat, sphagnum moss, bamboo leaf compost and combination media rice (rice husk charcoal : cocopeat $=1: 1$ ). The result showed

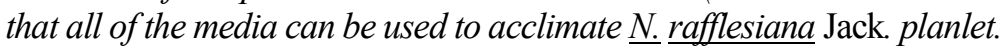

Key words : acclimatization, in vitro, media combination, Nepenthes $\underline{\text { rafflesiana }}$

\section{ABSTRAK}

Penelitian ini bertujuan untuk mempelajari pengaruh macam media aklimatisasi terhadap pertumbuhan $N$. rafflesiana Jack. dan untuk mendapatkan media yang paling sesuai untuk aklimatisasi. Penelitian dilakukan di Kebun Raya Bogor dari bulan Juni sampai dengan September 2009. Rancangan yang digunakan dalam percobaan adalah Rancangan Acak Lengkap (RAL) dengan tiga ulangan. Lima jenis media yang dipergunakan sebagai media aklimatisasi adalah arang sekam, cocopeat, sphagnum moss, kompos daun bambu dan kombinasi media campuran (arang sekam : cocopeat $=1: 1$ ). Hasil percobaan menunjukkan bahwa semua media dapat digunakan untuk aklimatisasi planlet $N$. rafflesiana Jack.

kata kunci: aklimatisasi, in vitro, kombinasi media, Nepenthes rafflesiana

\section{PENDAHULUAN}

Nepenthes atau kantong semar tumbuh dan tersebar mulai dari Australia bagian utara, Asia Tenggara, hingga Cina bagian selatan. Di Indonesia terdapat 64 jenis Nepenthes yang hidup pada berbagai ketinggian tempat dan habitat yang berbeda. Borneo (Kalimantan, Serawak, Sabah, dan Brunei) merupakan pusat penyebaran Nepenthes di dunia, tempat hidup asal 32 jenis Nepenthes. Sumatera menempati urutan kedua, terdapat 29 jenis Nepenthes ditemukan di pulau ini. Di Sulawesi, New Guinea, Maluku dan di Jawa masing-masing terdapat $10,9,4$ dan 2 jenis Nepenthes (Mansur, 2007).
Kantong semar memiliki kantong (pitcher) yang terbentuk di ujung daun berisi cairan yang menghasilkan enzim. Enzim ini dapat 'mencerna' serangga yang terjebak dalam cairan tersebut, sehingga tanaman ini dimasukkan dalam tumbuhan karnivora.

N. rafflesiana Jack. merupakan salah satu jenis kantong semar yang tumbuh dan tersebar di daerah Borneo, Sumatera, Semenanjung Malaysia dan Singapura. Tanaman ini tumbuh baik pada ketinggian 0-1 $200 \mathrm{~m}$ dari permukaan laut. Kantong semar biasanya tumbuh pada habitat tempat-tempat terbuka atau ternaungi yang basah atau kering seperti hutan rawa gambut dan hutan kerangas (Clarke, 1997).

\footnotetext{
Alumni Departemen Agronomi dan Hortikultura, Fakultas Pertanian, Institut Pertanian Bogor

${ }^{2}$ Staf Pengajar Departemen Agronomi dan Hortikultura, Fakultas Pertanian-Institut Pertanian Bogor, Jl. Meranti, Kompleks IPB

Darmaga Bogor, 16680.Indonesia. Telp Fax : 0251 8629353*Email korespondensi: wantamadsari@yahoo.com

${ }^{3}$ Pusat Konservasi Tumbuhan, Kebun Raya Bogor, LIPI
} 
N. rafflesiana Jack. menurut data tumbuhan yang terancam punah dalam daftar Red Data Book yang dikeluarkan oleh IUCN (2009) termasuk dalam status terkikis (Lower Risk/ Least Concern) (IUCN, 2009). CITES (2008) juga memasukkan $N$. rafflesiana Jack. ini ke dalam Appendix II, yang artinya segala bentuk kegiatan perdagangan tanaman ini sangat dibatasi, kecuali tanaman hasil budidaya. Nepenthes sebagai salah satu sumber keanekaragaman hayati Indonesia yang belum dimanfaatkan secara optimal. Tanaman ini memiliki nilai ekonomi cukup tinggi jika dikembangkan sebagai tanaman hias. Kantong semar dijadikan sebagai tanaman hias pilihan yang eksotis di Negara Jepang, Eropa, Amerika dan Australia. Namun, di Indonesia tanaman ini tidak banyak yang mengenal dan memanfaatkannya (Witarto, 2006).

Teknik perbanyakan Nepenthes dapat dilakukan dengan cara setek batang, biji, pemisahan anakan dan kultur jaringan (Mansur, 2007). Untuk menjaga kelestarian tanaman Nepenthes, maka diperlukan suatu metode budidaya yang tepat, sehingga dapat diperoleh tanaman dalam jumlah banyak dan dalam waktu yang relatif lebih cepat. Metode kultur jaringan merupakan salah satu cara perbanyakan untuk mendapatkan tanaman Nepenthes dalam jumlah banyak secara cepat.

Menurut Gunawan (1992) kultur jaringan merupakan suatu metode mengisolasi bagian dari tanaman seperti protoplasma, sel, sekelompok sel, jaringan dan organ, serta menumbuhkannya dalam kondisi aseptik, sehingga bagian-bagian tersebut dapat memperbanyak diri dan beregenerasi menjadi tanaman yang lengkap. Perbanyakan Nepenthes secara in vitro dengan eksplan yang berasal dari biji telah dilakukan pada $N$. mirabilis (Dinarti et al., 2010), N. gracilis (Isnaini dan Handini, 2007) dan N. ampularia (Isnaini, 2009). Hasil perbanyakan in vitro memerlukan proses aklimatisasi agar tanaman dapat tumbuh dan berkembang dengan baik.

Aklimatisasi merupakan proses penyesuaian peralihan lingkungan dari kondisi heterotrof ke lingkungan autotrof pada planlet tanaman yang diperoleh melalui teknik in vitro (Wattimena, 1992). Menurut Zulkarnain (2009) faktor-faktor yang mempengaruhi pertumbuhan planlet selama tahap aklimatisasi adalah media tanam, intensitas cahaya, kelembaban dan suhu ruang. Menurut Hartmann dan Kester (2002), media tumbuh yang ideal untuk tanaman secara umum adalah media yang memiliki syarat-syarat seperti struktur gembur, aerasi dan drainase yang baik serta kelembapan cukup, bebas organisme pengganggu dan bahan berbahaya seperti pestisida, cukup hara mineral dan bobotnya ringan. Rice (2009) menyatakan bahwa media yang dianggap cukup baik untuk pertumbuhan Nepenthes secara umum adalah sphagnum moss, akan tetapi di Indonesia relatif sulit untuk didapat dan harganya cenderung lebih mahal. Penggunaan media sphagnum moss secara terus menerus juga akan menyebabkan berkurangnya populasi sphagnum moss di alam.

Penelitian aklimatisasi pada planlet $N$. hookeriana menunjukkan bahwa tanaman layu dan mati akibat media yang digunakan selama tahap aklimatisasi kurang sesuai dan tidak steril sehingga memicu tumbuhnya cendawan seperti Pythium sp. (Iqwal, 2008). Berdasarkan kondisi tersebut, maka diperlukan penelitian yang mempelajari pengaruh macam media aklimatisasi terhadap pertumbuhan $N$. rafflesiana Jack. untuk mendapatkan media yang paling sesuai untuk aklimatisasi.

\section{BAHAN DAN METODE}

Penelitian ini dilaksanakan pada bulan Juni sampai September 2009. Aklimatisasi dilakukan di Rumah Paranet Laboratorium Kultur Jaringan Kebun Raya Bogor.

Bahan tanaman yang dipergunakan dalam penelitian ini adalah planlet $N$. rafflesiana Jack. berumur 1 tahun yang berasal dari hasil perbanyakan secara in vitro di Laboratorium Kultur Jaringan Kebun Raya Bogor. Media tanam yang dipergunakan sebagai media aklimatisasi adalah arang sekam, cocopeat, sphagnum moss dan kompos daun bambu.

Percobaan menggunakan rancangan lingkungan berupa rancangan acak lengkap (RAL) dengan faktor tunggal. Percobaan ini terdiri atas 5 perlakuan media aklimatisasi yaitu jenis media tanam arang sekam, cocopeat, sphagnum moss, kompos daun bambu dan media campuran cocopeat dengan arang sekam (1:1). Setiap perlakuan diulang 3 kali dan setiap unit percobaan terdiri atas 10 tanaman.

Persiapan media tanam dilakukan di luar ruangan laboratorium. Media aklimatisasi yang digunakan terdiri atas arang sekam, sphagnum moss, kompos daun bambu, cocopeat dan kombinasi antara arang sekam dan cocopeat (1:1). Media cocopeat dan daun bambu disterilisasi dengan cara di autoklaf pada suhu $121{ }^{\circ} \mathrm{C}$, selama 20 menit. Sebelum dipergunakan, semua media disterilisasi dengan direndam dalam air panas, sampai air menjadi dingin. Media perlakuan kemudian dimasukkan ke dalam botol plastik dalam keadaan lembab. 
Penanaman planlet pada media aklimatisasi dilakukan di rumah paranet. Planlet terlebih dahulu dicuci dengan menggunakan air bersih. Proses pencucian ini bertujuan untuk membersihkan planlet dari media kultur yang masih tersisa di akar karena sisa media akan menjadi media jamur. Selanjutnya planlet ditanam dalam media sesuai perlakuan dalam botol plastik dan ditutup dengan penutup plastik. Setelah itu, botol berisi planlet Nepenthes disimpan dalam rumah paranet dengan kerapatan sekitar $80 \%$.

Pengamatan pertumbuhan $N$. rafflesiana Jack. selama tahap aklimatisasi dilakukan setiap minggu selama dua bulan. Peubah yang diamati adalah jumlah daun, tinggi tanaman, jumlah akar, jumlah kantong, pertambahan ukuran tinggi kantong, pengamatan kualitatif yang dilakukan berupa warna daun dan warna kantong, persentase jumlah tunas yang muncul selama pengamatan, persentase jumlah daun yang layu dan persentase jumlah tanaman yang mati. Beberapa peubah lingkungan yang diamati adalah suhu ruang, kelembaban udara dan intensitas cahaya. Pengamatan ini dilakukan setiap hari, pada pagi dan siang hari. Pengamatan $\mathrm{pH}$ pada media perlakuan dilakukan pada minggu ke 5 dan minggu ke 7.

\section{HASIL DAN PEMBAHASAN}

\section{Pengukuran pH Media dan Peubah Lingkungan}

Pengukuran $\mathrm{pH}$ media yang dilakukan pada minggu ke 5 dan ke 7 menunjukan bahwa nilai rata-rata $\mathrm{pH}$ media berkisar antara 4.2 hingga 6 (Tabel 1). Pada media arang sekam, nilai $\mathrm{pH}$ nya relatif lebih tinggi dibandingkan dengan media lain yaitu sekitar 6. Menurut Robert dan Oosting (1958), $\mathrm{pH}$ media yang sesuai untuk pertumbuhan tanaman karnivora adalah berkisar antara 3-6.

\section{Pertambahan Jumlah Daun}

Pertambahan jumlah daun $N$. rafflesiana Jack. pada perlakuan beberapa media tanam tidak menunjukkan perbedaan yang nyata. Rata-rata pertumbuhan daun per minggu $N$. rafflesiana Jack. sekitar 0.5 daun per minggu (Tabel 1).

Berdasarkan data kuantitatif yang diperoleh selama 8 minggu pengamatan, tanaman yang tumbuh pada media arang sekam memiliki nilai rataan jumlah daun yang paling sedikit dibandingkan dengan media tanam yang lain. Pertambahan jumlah daun terbanyak dijumpai pada tanaman yang tumbuh pada media cocopeat (Tabel 1).

\section{Pertambahan Tinggi Batang}

Berdasarkan hasil sidik ragam, pertambahan tinggi batang tanaman Nepenthes pada perlakuan media tanam memberikan hasil yang tidak berbeda nyata. Pertambahan tinggi tanaman yang tumbuh pada media cocopeat dan daun bambu relatif lebih tinggi, yaitu sebesar $0.065 \mathrm{~cm}$ minggu per tanaman (Tabel 1). Hal ini diduga terjadi karena struktur media tersebut memiliki porositas yang baik.

Secara umum pertambahan rata-rata tinggi batang Nepenthes pada setiap minggunya hanya berkisar 0.5-0.6 mm minggu ${ }^{-1}$. Pada tanaman yang lebih muda (dengan kriteria ukuran daun yang masih kecil) pertambahan tinggi batang lebih cepat dibandingkan dengan tanaman yang lebih tua (daun yang lebar). Hal ini diduga karena pada tanaman muda akumulasi unsur hara yang ditranportasikan dari akar menuju tanaman, lebih tertuju pada pertumbuhan batang dan tunas daun, sedangkan pada tanaman yang lebih tua, akumulasi unsur dari akar menuju tanaman lebih tertuju pada pertumbuhan daun.

Pertumbuhan tanaman Nepenthes relatif lambat, hal ini dapat terlihat pada pertambahan tinggi batang. Mansur (2007) menyatakan bahwa pertumbuhan tanaman Nepenthes akan lebih baik apabila terdapat pada lingkungan yang sesuai dengan habitat hidupnya di alam, dimana sebagian besar Nepenthes hidup di tempat-tempat terbuka atau pada tempat yang sedikit terlindungi dan miskin unsur hara serta memiliki kelembaban yang cukup tinggi.

\section{Pertambahan Jumlah Akar}

Penghitungan jumlah akar dilakukan pada awal dan akhir pengamatan. Hal ini dilakukan agar tidak merusak perakaran selama tahap aklimatisasi karena struktur akar planlet Nepenthes masih tipis dan mudah putus. Bentuk perakaran Nepenthes termasuk dalam akar serabut dengan beberapa akar sekunder dan tersier yang cukup banyak.

Pertambahan jumlah akar Nepenthes yang tumbuh pada berbagai perlakuan media tanam tidak berbeda nyata. Jumlah akar berbeda walaupun sedikit, statistiknya tidak berbeda nyata. Rata-rata jumlah akar setelah dua bulan aklimatisasi berkisar antara 5.1 hingga 6.5 akar. Pada penelitian ini, $N$. rafflesiana Jack. yang tumbuh pada media cocopeat memiliki jumlah akar yang relatif lebih banyak dibandingkan dengan media lainnya (Tabel 1). Akar yang banyak dan sehat akan mempercepat pertumbuhan tanaman sampai dua kali lipat. 
Tabel 1. Pertambahan jumlah dan ukuran tinggi kantong $N$. rafflesiana Jack. yang tumbuh pada berbagai media aklimatisasi

\begin{tabular}{|c|c|c|c|c|}
\hline \multirow{2}{*}{ Perlakuan } & \multirow{2}{*}{$\begin{array}{c}\mathrm{Ph} \\
\text { Rata- } \\
\text { rata }\end{array}$} & \multicolumn{3}{|c|}{ Rata-rata Pertambahan } \\
\hline & & JD & ТВ & JA \\
\hline $\begin{array}{l}\text { Arang } \\
\text { sekam }\end{array}$ & 6 & 0.5 & 0.064 & 5.3 \\
\hline Cocopeat & 5 & 0.6 & 0.065 & 6.5 \\
\hline $\begin{array}{l}\text { Daun } \\
\text { bambu }\end{array}$ & 4.2 & 0.5 & 0.065 & 5.7 \\
\hline Kombinasi & 5.7 & 0.5 & 0.061 & 5.1 \\
\hline $\begin{array}{l}\text { Spaghnum } \\
\text { moss }\end{array}$ & 4.3 & 0.5 & 0.058 & 5.6 \\
\hline Uji F & - & tn & tn & tn \\
\hline
\end{tabular}

Keterangan: JD = Rata-rata pertambahan jumlah daun per minggu; $\mathrm{TB}=$ Rata-rata pertambahan tinggi batang per minggu; $\mathrm{JA}=$ Rata-rata pertambahan jumlah akar; $\mathrm{tn}=$ Tidak berbeda nyata pada uji $\mathrm{F}$ dengan $\alpha=5 \%$

Tabel 2. Pertambahan jumlah dan ukuran tinggi kantong $N$. rafflesiana Jack. yang tumbuh pada berbagai media aklimatisasi

\begin{tabular}{lcc}
\hline \multirow{2}{*}{ Perlakuan } & \multicolumn{2}{c}{ Rata-Rata Pertambahan } \\
\cline { 2 - 3 } & $\begin{array}{c}\text { Jumlah } \\
\text { Kantong per } \\
\text { Minggu }\end{array}$ & $\begin{array}{c}\text { Tinggi } \\
\text { Kantong per } \\
\text { Minggu }\end{array}$ \\
\hline Arang sekam & 0.6 & 0.15 \\
Cocopeat & 0.8 & 0.17 \\
Daun bambu & 0.7 & 0.16 \\
Kombinasi & 0.7 & 0.18 \\
Spaghnum & 0.7 & 0.14 \\
moss & tn & tn \\
Uji F & & \\
\hline
\end{tabular}

\section{Pertambahan Jumlah Kantong}

Pertambahan jumlah kantong $N$. rafflesiana Jack. pada perlakuan beberapa media tanam tidak menunjukkan perbedaan yang nyata. Pertambahan jumlah kantong per minggu yang paling banyak dijumpai pada tanaman yang tumbuh pada media cocopeat. Pertambahan jumlah kantong paling sedikit dijumpai pada tanaman yang tumbuh pada media arang sekam (Tabel 2). Pertambahan jumlah kantong pada tanaman Nepenthes, berkaitan dengan ketersediaan unsur hara yang terkandung pada setiap media. Menurut Mansur (2007), tanaman Nepenthes akan memodifikasi ujung daunnya menjadi kantong perangkap, hal tersebut bertujuan untuk mensuplai nutrisi makanan yang kurang tersedia dari media tanam yang digunakan.

\section{Pertambahan Ukuran Tinggi Kantong}

Pengukuran tinggi kantong dilakukan pada minggu ke 6 hingga minggu ke 8 . Hasil sidik ragam menunjukan bahwa perlakuan media tanam tidak memberikan pengaruh yang nyata terhadap pertambahan tinggi kantong. Rata-rata pertambahan tinggi kantong yang paling cepat dijumpai pada tanaman yang tumbuh pada media kombinasi sebesar $0.18 \mathrm{~cm}$ per minggu. Pertambahan tinggi kantong yang paling lambat dijumpai pada tanaman yang tumbuh pada media sphagnum moss (Tabel 2).

\section{Penampakan Secara Visual}

Warna daun semua $N$. rafflesiana Jack. selama tahapan aklimatisasi seragam, yaitu berwarna hijau muda. Namun, beberapa daun terlihat berwarna hijau tua atau menguning. Hal ini diduga karena pengaruh $\mathrm{pH}$ pada media perlakuan. Warna kantong $N$. rafflesiana Jack. selama pengamatan secara umum seragam, yaitu berwarna hijau tua. Penampakan secara visual tanaman $N$. rafllesiana Jack. setelah aklimatisasi selama dua bulan berbeda (Gambar 1). Nepenthes yang tumbuh pada media cocopeat memiliki perakaran lebih banyak dibandingkan dengan Nepenthes yang tumbuh pada media lainnya. Struktur daun terlihat lebih kecil dengan ukuran kantong yang cukup besar. Nepenthes yang tumbuh pada media sphagnum moss memiliki perakaran sangat sedikit, ukuran tanaman dan kantong lebih kecil dibandingkan dengan tanaman yang tumbuh pada media lainnya, tetapi memiliki jumlah kantong yang relatif lebih banyak. Nepenthes yang tumbuh pada media kombinasi memiliki daun yang lebih lebar dan daun berwarna lebih hijau. Nepenthes yang tumbuh pada media humus daun bambu, memiliki ukuran kecil dan memiliki banyak rambut akar/akar sekunder. Nepenthes yang tumbuh pada media arang sekam memiliki perakaran relatif banyak namun memiliki beberapa daun yang menguning atau layu.

\section{Persentase Tunas Baru}

Pengamatan pada persentase jumlah tunas baru yang muncul setelah 2 bulan aklimatisasi menunjukkan bahwa tanaman yang tumbuh pada media spaghnum moss memiliki persentase tertinggi 
(6\%). Tanaman yang tumbuh pada arang sekam tidak menghasilkan tunas baru, sedangkan tanaman yang tumbuh pada media cocopeat, daun bambu, dan media kombinasi 3\% tanaman menghasilkan tunas baru (Tabel 3).

\section{Persentase Daun yang Layu dan Bercak}

Secara visual, warna daun $N$. rafflesiana Jack. yang tumbuh pada beberapa media tidak berbeda. Hasil pengamatan pada persentase jumlah daun yang layu ataupun berbecak cokelat menunjukkan bahwa tanaman yang tumbuh pada media arang sekam memiliki jumah daun yang layu/berbecak cokelat paling banyak (26\%). Tanaman yang tumbuh pada media cocopeat memiliki jumlah daun layu/berbecak paling sedikit (3\%) (Tabel 3).

Kondisi lingkungan tumbuh yang digunakan pada tahap aklimatisasi ini, sangat berpengaruh terhadap pertumbuhan planlet Nepenthes. Tjondronegoro dan Harran (1984) dalam Tjitrosomo (1984) menyatakan bahwa faktor-faktor luar yang mempenganuhi pertumbuhan tanaman adalah ketersediaan hara mineral, kadar air dan udara di dalam tanah, kelembaban udara, intensitas cahaya, lamanya penyinaran serta suhu. Setiap faktor dari hal-hal tersebut dapat menjadi faktor pembatas bagi pertumbuhan.

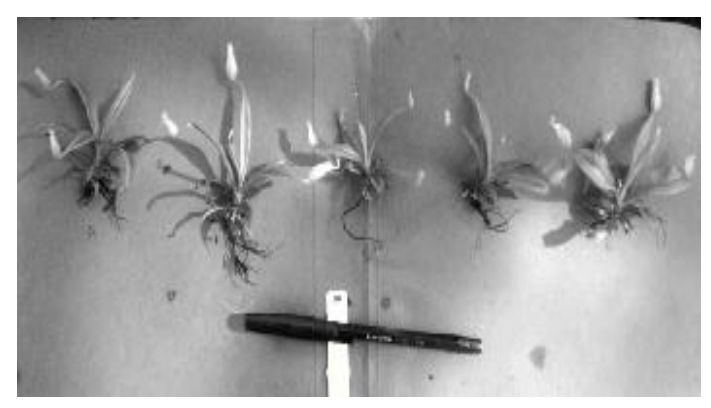

Gambar 1. Penampilan tanaman N. rafflesiana Jack. setelah 2 bulan aklimatisasi; Keterangan: pengambilan tanaman contoh, dipilih berdasarkan ukuran (jumlah daun, bentuk daun dan tinggi batang) yang hampir seragam pada awal pengamatan; A: media arang sekam; B: media cocopeat; S: media sphagnum moss; D: media daun bambu; dan K: media kombinasi
Tabel 3. Persentase jumlah daun dan tunas yang terbentuk dan layu atau terdapat bercak cokelat pada $N$. rafflesiana Jack. beberapa media perlakuan setelah 2 bulan aklimatisasi

\begin{tabular}{lcc}
\hline Perlakuan & $\begin{array}{c}\text { Persentase } \\
\text { Muncul } \\
\text { Tunas (\%) }\end{array}$ & $\begin{array}{c}\text { Persentase } \\
\text { Jumlah Daun } \\
\text { yang Layu atau } \\
\text { Terdapat Bercak } \\
\text { Cokelat (\%) }\end{array}$ \\
\hline Arang sekam & 0 & 26 \\
Cocopeat & 3 & 3 \\
Daun bambu & 3 & 16 \\
Kombinasi & 3 & 13 \\
Spaghnum moss & 6 & 13 \\
\hline
\end{tabular}

Selama tahap aklimatisasi Nepenthes berlangsung, suhu ruangan di rumah paranet pada pagi hari berkisar antara $24-31{ }^{\circ} \mathrm{C}$ dan pada siang hari suhu ruangan berkisar $27-37^{\circ} \mathrm{C}$. Kelembaban udara di rumah paranet pada pagi hari berkisar antara 51-97\% dan pada siang hari berkisar 46$93 \%$. Intensitas cahaya matahari yang masuk pada pagi hari berkisar antara 11.6 - 316 Lux dan pada siang hari berkisar antara 29 - 648 Lux. Menurut Mansur (2007), suhu udara untuk pertumbuhan Nepenthes secara umum yaitu berkisar antara 23$31{ }^{\circ} \mathrm{C}$, sedangkan untuk kelembaban udara, berkisar antara $50-70 \%$. Hal ini merupakan persyaratan yang harus dilakukan pada saat memelihara Nepenthes dataran rendah. Hal tersebut dipertegas oleh Rice (2009) yang menyatakan bahwa, Nepenthes jenis dataran rendah akan tumbuh lebih baik pada suhu $30-34{ }^{\circ} \mathrm{C}$ (pada siang hari) dan suhu terendah pada malam hari sekitar $8{ }^{\circ} \mathrm{C}$, sedangkan untuk kelembaban udara yang baik berkisar antara 60$80 \%$ untuk semua jenis Nepenthes.

Hasil penelitian aklimatisasi ini mengindikasikan bahwa semua media perlakuan dapat digunakan untuk aklimatisasi $N$. rafflesiana Jack. Hal ini dapat terlihat dari sidik ragam yang dilakukan, dimana hasil yang diperoleh pada semua parameter pengamatan tidak berbeda nyata. Semua $N$. rafflesiana Jack. dapat tumbuh dengan baik sampai akhir pengamatan aklimatisasi. Pencucian planlet dan sterilisasi media sebelum digunakan dapat mencegah serangan jamur Phytium sp. Jamur ini ditemukan pada aklimatisasi $N$. hookerina yang dilakukan Iqwal (2008), karena media tidak disterilisasi sehingga media yang tersisa menjadi berjamur.

Secara visual dapat terlihat perbedaan yang muncul pada setiap perlakuan, seperti warna daun, yang menguning ataupun yang layu akibat media yang kurang sesuai. Pada media arang sekam terdapat beberapa helai daun (sekitar 26\%) yang 
layu atau pun terdapat bercak cokelat, hal ini diduga karena pengaruh derajat keasaman media tanam yang mencapai $\mathrm{pH} \mathrm{6.} \mathrm{Menurut} \mathrm{Mansur}$ (2007), tanaman $N$. rafflesiana Jack. biasanya tumbuh di hutan kerangas atau lahan gambut yang miskin unsur hara dan memiliki $\mathrm{pH}$ rendah, sedangkan nilai $\mathrm{pH}$ media pada arang sekam mendekati netral yaitu dengan nilai $\mathrm{pH} 6$.

Pertambahan jumlah kantong paling banyak dijumpai pada Nepenthes yang tumbuh pada media cocopeat dengan nilai rata-rata pertambahan sebesar 0.8 kantong per minggu, sedangkan untuk pertambahan ukuran kantong yang paling cepat, dijumpai pada Nepenthes yang tumbuh pada media campuran dengan nilai rata-rata pertambahan sebesar $0.18 \mathrm{~cm}$ per minggu. Menurut Clarke (1997), proses pembentukan kantong pada tanaman Nepenthes di alam berkaitan dengan usahanya untuk tetap sintas di habitatnya yang miskin hara.

Jumlah anakan yang banyak muncul terdapat pada media sphagnum moss sebanyak $6 \%$, hal ini diduga karena ketersediaan unsur hara yang terdapat pada media tersebut sehingga memacu pertumbuhan tunas baru. Menurut Wiryanta (2007), kelebihan dari media sphagnum moss adalah kemampuan mengikat air sampai $80 \%$ dan mengandung nitrogen sebanyak 2-3\%.

Penggunaan media sphagnum moss yang umumnya digunakan pada tahapan aklimatisasi $N$. rafflesiana Jack. ternyata perannya dapat tergantikan oleh media tanam yang lain. Dalam penelitian ini hampir semua media dapat digunakan untuk menumbuhkan tanaman $N$. rafflesiana Jack. Salah satu media yang relatif lebih baik dibandingkan dengan media lainnya adalah media cocopeat. Dengan diperolehnya media pengganti sphagnum moss ini, diharapkan keberadaan moss di alam dapat terpelihara dan terjaga dengan baik sehingga terhindar dari eksploitasi yang bisa mengganggu keseimbangan ekosistem di alam.

\section{KESIMPULAN}

Semua media tanam aklimatisasi yang digunakan dalam penelitian ini, dapat memacu pertumbuhan planlet $N$. rafflesiana Jack. Berdasarkan hasil uji $\mathrm{F}$ pada semua peubah perlakuan yaitu pertambahan jumlah daun, pertambahan jumlah kantong, pertambahan tinggi tanaman, pertambahan jumlah akar dan pertambahan tinggi kantong, menunjukkan bahwa perlakuan media tanam aklimatisasi tidak berpengaruh nyata terhadap semua peubah yang diamati. Hal tersebut menunjukkan bahwa tidak hanya media arang sekam atau pun sphagnum moss saja yang dapat digunakan untuk menumbuhkan planlet $N$. rafflesiana Jack. tetapi media yang lain seperti cocopeat, daun bambu dan kombinasi (cocopeat: arang sekam) dapat juga dijadikan sebagai media aklimatisasi Nepenthes. Pada media arang sekam, persentase jumlah tanaman yang terkena bercak daun ataupun terkena

\section{SARAN}

Berdasarkan penelitian yang telah dilakukan, disarankan menggunakan media cocopeat untuk tahap aklimatisasi $N$. rafflesiana Jack. karena selain harganya yang murah, media cocopeat juga merupakan media terbaik untuk menumbuhkan planlet $N$. rafflesiana Jack. pada penelitian aklimatisasi ini. Pengujian kandungan hara pada masing-masing media perlakuan, diperlukan sehingga dapat diketahui unsur-unsur hara yang terkandung dalam setiap media.

\section{DAFTAR PUSTAKA}

Annisa. 2009. Media tanam alternative selain tanah. http://www.kompas.com. [14 April 2009].

Azwar, F., K. Adi, R.S. Teten. 2006. Kantong Semar (Nephentes sp.) di Hutan Sumatera, tanaman unik yang semakin langka. Makalah Penunjang pada Ekspose Hasilhasil Penelitian: Konservasi dan Rehabilitasi Sumberdaya Hutan. Padang, 20 September 2006. http://www.dephut.go.id/ files/Fatahul-Azwar.pdf. [7 April 2009].

CITES. 2008. Convention on International Trade in Endangered Species of Wild Fauna and Flora. Seventeenth Meeting of The Plants Committee Geneva (Switzerland), 15-19 April 2008.

Clarke, C. 1997. Nepenthes of Borneo. Natural History Publications. Kinabalu.

Diniarti, D., U. Sayekti, Y. Alitalia. 2010. Kultur Jaringan Kantung Semar (Nepentus Mirabilis). J. Hort. Indonesia. 1(2): 59-65. 
Gunawan. L.W. 1992. Teknik Kultur Jaringan Tumbuhan. Laboratorium Kultur Jaringan Tanaman. PAU Bioteknologi IPB. Bogor.

Hartmann, H.T., D.E. Kester. 2002. Plant Propagation, Principles and Practices. Sixth edition. Prentice Hall. New Delhi. India.

IUCN. 2009. Red List of Threatened Species. Version 2009. 1. www.iucnredlist.org. [26 Juni 2009].

Isnaini, Y. 2009. Perkecambahan biji Kantong Semar (Nepenthes ampullaria Jack.) pada berbagai media in vitro dan di rumah kaca. Pusat Konservasi Tumbuhan Kebun Raya Bogor. LIPI. Bogor.

Isnaini, Y.E. Handini. 2007. Perkecambahan biji Kantong Semar (Nepenthes gracilis Korth.) secara in vitro. Buletin Kebun Raya 10(2): 40-46.

Iqwal, M.T. 2008. Pengujian berbagai media aklimatisasi untuk menumbuhkan planlet Kantong Semar (Nepenthes spp.). Skripsi. Departemen Ilmu Tanah dan Sumberdaya lahan, Fakultas Pertanian Institut Pertanian Bogor. Bogor.

Mansur, M. 2007. Nepenthes, Kantong Semar yang Unik. Penebar Swadaya. Jakarta.

Rice, A.B. 2009. Growing Carnivorous Plants. Timber Press.
Roberts, P.R., H.J. Oosting. 1958. Responses of Venus fly trap (Dionaea muscipula) to factors involved in its endemism. Ecol. Monographs. 28: 193-218.

Suska, M.A. 2005. Nepenthes mirabilis vegetarian dari keluarga karnivora. Trubus 433, Halaman 88-89.

Tjitrosomo, S.S. 1984. Botani Umum 3. Angkasa. Bandung.

Wattimena, G.A., L.W. Gunawan, N.A. Mattjik, E. Syamsudin, N.M.A. Wiendi, A. Ernawati. 1992. Bioteknologi Tanaman. Direktorat Jenderal Pendidikan Tinggi Pusat Antar Universitas Bioteknologi, Institut Pertanian Bogor.

Witarto, A.B. 2006. Protein pencerna di Kantong Semar. Lembaga Ilmu Pengetahuan Indonesia. http://www.lipi.go.id. [25 Mei 2008].

Wiryanta, B.T.W. 2007. Media Tanam untuk Tanaman Hias. Agromedia Pustaka. Jakarta Selatan.

Zulkarnain. 2009. Kultur Jaringan Tanaman. [Editor] R. Rachmatika. Bumi Aksara. Jakarta. 